\title{
A ERA DAS INDEPENDÊNCIAS NA OBRA de Ahmadou Kourouma
}

\author{
Adalberto Gregório $B A C K^{*}$ \\ Kedrini Domingos dos SANTOS ${ }^{* *}$
}

\begin{abstract}
RESUMO: O escritor costa-marfinense Ahmadou Kourouma (1927-2003) aborda a temática da colonização africana e da era das independências em Os sóis das independências, romance publicado em 1968. Partindo do contexto social da Costa do Marfim dos anos 1960, o autor cria uma obra romanesca que nos permite entrever o universo pós-colonial através do percurso do personagem Fama, príncipe Horodougou despojado de seu título, seus bens e de sua dignidade. Pretendemos observar, neste artigo, como se deu o processo de colonização e de independência da Costa do Marfim e pensar, a partir da perspectiva apresentada por Ahmadou Kourouma no romance, a questão da degradação da tradição malinké na era das independências.
\end{abstract}

PALAVRAS-CHAVE: Ahmadou Kourouma. Les Soleils des indépendances. Colonização. Independência.

A literatura tem um papel importante na sociedade, pois permite-nos aprender mais sobre outras culturas e outros mundos, como o universo africano, o qual ainda permanece desconhecido para a maior parte da população brasileira. O romance Les soleils des indépendances (1983), ou, Os sóis das independências (1970), do escritor costa-marfinense Ahmadou Kourouma (1927-2003) foi publicado em 1968 e faz referência à independência da Costa do Marfim, em 1960. O país fazia, até então, parte do território africano colonizado pela França, em decorrência do processo de expansão do imperialismo europeu no século XIX.

UFSCar - Universidade Federal de São Carlos. Programa de Pós-Graduação em Ciência Política. São Carlos - SP - Brasil. 13565-905 - backgregor@hotmail.com

* UNESP - Universidade Estadual Paulista. Faculdade de Ciências e Letras de Araraquara. Programa de Pós-Graduação em Estudos Literários. Araraquara - SP - Brasil. 14800-901 - santkelife@gmail.com 
A conquista imperialista na África deu-se por vários motivos. Em plena Revolução Industrial, a Europa necessitava de matérias-primas e minerais que não eram encontrados no continente europeu. Além disso, havia o desejo, por parte dos grandes Estados, de afirmar sua força, seu poder e influência e para isso viram a necessidade de anexar territórios na África e na Ásia. Em meados de 1870, o tema da África ocasiona conflitos entre as potências europeias e, para evitar confrontos abertos, a Conferência de Berlim, de 1884-1885, que contou com a participação de vários países europeus, dos Estados Unidos e da Turquia, regulamenta a ocupação e as áreas de influência e domínio na África (BOAHEN, 1987).

$\mathrm{Na}$ França, o discurso colonialista na segunda metade do século XIX marca a eclosão do racismo científico e da teoria da hierarquia das raças, com a publicação do Ensaio sobre a desigualdade das raças humanas, em 1853-1855, de Arthur Gobineau (1816-1882)1, assim como trabalhos de antropólogos e naturalistas que, a partir da craniometria ou da cor da pele, pretendem provar que a raça negra é inferior à raça branca, a qual era vista como superior e civilizada. A imprensa popular, os livros de aventura e as exposições também tiveram um papel importante na construção da imagem do africano como selvagem, discurso que visa legitimar a colonização.

Em 1884, Jules Ferry (1832-1893), político influente francês e defensor ativo da expansão colonialista, buscando justificar uma missão civilizadora, afirma na Câmara dos Deputados: "Se temos o direito de ir a esses bárbaros, é porque temos o dever de civilizá-los. [...] Não devemos tratá-los como iguais, mas nos colocarmos no ponto de vista de uma raça superior que conquista." (FERRY apud MANCERON, 2004, p.60, tradução nossa). O filósofo Ernest Renan (1823-1892), por sua vez, entende que: "A colonização em grande escala é uma necessidade política de primeira ordem. Uma nação que não coloniza é irrevogavelmente condenada ao socialismo, à guerra do rico e do pobre. A conquista de um país de raça inferior por uma raça superior, que se instala ali para governá-lo, não é chocante." (RENAN, 1950, p.62, tradução nossa).

Segundo Eugène Etienne (1844-1921), subsecretário de Estado nas colônias entre 1887 e 1892 e presidente do grupo colonial na Câmara dos deputados em 1895, a colonização é necessária “[...] para garantir o futuro do nosso país nos novos continentes, para reservar uma saída para nossos produtos e encontrar matériasprimas para nossas indústrias." (FRANCE, 1894, p.404, tradução nossa). As plantações e explorações de matérias-primas são a finalidade essencial das colônias, entretanto, a França busca passar a impressão de que a colonização se faz em nome dos direitos do homem, como se o objetivo fosse colocar fim à escravidão e levar progresso e civilização à África.

Conferir Gobineau (2004). 
A França ocupa, desde a segunda metade do século XIX, vastas extensões territoriais no mundo. Instalada no Oriente, na América, na Oceania e na Índia, a África surge como o maior domínio colonial francês, cujo território era compreendido por países no Magrebe, região situada na parte ocidental da África do Norte, entre o mar Mediterrâneo, o oceano Atlântico e o Egito; na África Ocidental Francesa (AOF) e na África Equatorial Francesa (AEF). No Magrebe, a França ocupa a Argélia, a Tunísia e o Marrocos, colônias do tipo povoamento. A AEF possuía quatro colônias: Gabão, Médio Congo (atual República do Congo), Chade e Ubangi-Chari (atual República Centro-Africana), enquanto a AOF era um governo geral com oito colônias francesas, do tipo exploração, dentre as quais podemos citar Senegal, Guiné, Mauritânia, Mali, Costa do Marfim e Nigéria. Madagascar e Somália completam as colônias francesas na África (BOAHEN, 1987).

A política colonial francesa variava de acordo com a zona colonizada, mas em geral o colonialismo é descrito como um sistema de dominação e de administração direta, com forte intervenção nas estruturas autóctones africanas. Esse sistema tinha uma política de assimilação cultural e os territórios africanos foram considerados partes da França. A colonização direta realiza-se sistematicamente, seja pelos acordos estabelecidos com os chefes locais, seja pelas frequentes guerras e violência. Há ainda a instalação de administradores, mercadores e missionários franceses, além de um controle militar da área colonizada. Os povos autóctones são expropriados, as riquezas são exportadas a despeito da subsistência local e a mão de obra é mal paga ou submetida a trabalhos forçados, caso da construção da estrada de ferro CongoOceano (THIMONIER, 2006).

A colonização da Costa do Marfim fez-se a partir dessas diretrizes: a conquista colonial, a instauração da administração e a exploração da colônia. Inicialmente, ela ocorre de forma pacífica, entre 1893-1908, momento em que há a exploração do litoral, a aproximação com os chefes locais, a fim de assinar tratados com eles, e a instalação de postos militares, representando a autoridade e a bandeira francesa. Embora os missionários franceses tenham convertido parte dos animistas que habitavam a zona litorânea à fé católica, os povos da região já tinham uma relação com o islamismo, devido às relações comerciais entre os mulçumanos do norte da África e os chefes tribais, e tal situação impôs resistência, por parte dos colonos, à penetração dos missionários e dos militares nas savanas do Norte. Devido a isso, houve várias insurreições: o chefe Samory Touré, um dos maiores rebeldes, conseguiu resistir à penetração e à colonização francesa, mas foi capturado em 1898 e morreu na prisão em 1900. Assim, até 1908, a França controlava apenas parte do território, enquanto algumas regiões ainda eram hostis à política de colonização. Foram várias as causas de resistência, como a recusa das populações em abandonar suas autoridades locais em proveito dos franceses; o 
desejo da população costeira de controlar o comércio entre as populações internas e os europeus ou, ainda, a recusa de alguns nativos de ter qualquer contato com os estrangeiros (DAGO, 2016).

No entanto, a política pacífica já não era satisfatória para a França, situação que desencadeou a aplicação de outra política de colonização, entre 1908 e 1915, mais violenta, a fim de conter a resistência. Nesse caso, há reforço militar para consolidar a política de repressão, destruição de vilas e acampamentos rebeldes, desarmamento da população e prisão e deportação dos chefes de guerra. Tal repressão reduziu fortemente a população e, em 1920, todo o território da costamarfinense estava pacificado. As consequências da colonização são numerosas. Como são submetidos às autoridades francesas, esses povos perdem sua autonomia e os resistentes são deportados ou aprisionados. No âmbito político, os chefes tradicionais perdem o poder, sendo destituídos pela administração colonial em proveito de pessoas que cooperam com eles. $\mathrm{O}$ enfraquecimento do poder tradicional e as diversas transformações ocorridas na sociedade são percebidas no modo de vida das populações colonizadas, que se veem mergulhadas em valores e costumes que lhes são estranhos (DAGO, 2016).

Por meio da administração direta, a França impôs sua vontade aos habitantes da Costa do Marfim até 1960, ano da independência. O processo de descolonização das zonas ocupadas pelos franceses na África foi um processo difícil. A guerra da Argélia (1954-1962), por exemplo, foi uma das mais terríveis guerras africanas de independência no contexto de descolonização, com a morte de milhares de argelinos. No caso da Costa do Marfim, houve um referendo, em 1958, a partir do qual o país se tornou uma República autônoma e em 7 de agosto de 1960 o país se torna independente. No entanto, a Costa do Marfim ainda permaneceu ligada à França, porque sua moeda era dirigida pelo Banco da França e os investimentos franceses tornam a economia costa-marfinense dependente do país europeu. O presidente Félix Houphouët-Boigny, apoiado por seu partido único, o Partido Democrata da Costa do Marfim (PDCI), é constantemente reeleito a cada 5 anos, desde 1965. Além disso, seu partido único ocupava todas as cadeiras na Assembleia Nacional. Em 1961, ele assina um acordo de assistência militar com a França. Em 1990, próximo de sua morte, Félix Houphouët-Boigny abre a via da democratização através de algumas reformas, como a autorização de formação partidos políticos, de modo que, pela primeira vez, após 30 anos, houve dois candidatos à eleição presidencial (PENNA FILHO, P.; BADOU, 2014).

Assim, apesar da independência, a França persistiu em suas intervenções na Costa do Marfim, de 1960 até meados de 1990, mas essa intervenção deu-se de forma indireta e foi feita em conformidade com os setores das elites locais que dela se beneficiavam. O apoio da França foi crucial para a manutenção de numerosos 
dirigentes africanos no poder, sobretudo no período imediato à descolonização; em contrapartida, após a independência, foram assinados acordos de cooperação, com assistência técnica e financeira e cooperação militar, assim como a instalação de tropas francesas nos países considerados estratégicos para a França, como Senegal, Gabão e Costa do Marfim. É nesse contexto conturbado que surge o escritor Ahmadou Kourouma.

\section{Kourouma e o malinké}

Ahmadou Kourouma nasceu em 1927, em Boundiali, no norte da Costa do Marfim e pertencia ao grupo étnico malinké. Filho de pais separados, foi educado por um tio que lhe ensinou as tradições dos malinkés e suas referências geo-culturais e religiosas, assim como seu engajamento político, vão marcar profundamente sua obra.

A população da Costa do Marfim é multiétnica e, antes da colonização, os territórios eram divididos de acordo com as tribos. A colônia tinha aproximadamente 60 grupos étnicos ou tribos, e a mesma diversidade de línguas ou de dialetos, os quais eram divididos em quatro grupos principais: No centro, leste e sudeste, havia o grupo Akans, parentes dos habitantes de Gana e distribuídos entre Baoulés e Sanwis; o norte e nordeste era ocupado pelos Sénoufos; a sudoeste e oeste, na fronteira com a Libéria, havia os Krous e ocupando parte do norte (noroeste e nordeste) e parte do oeste estava o grupo Mandé do Norte, compostos essencialmente de etnias Malinké (também conhecidas como Mandingues), como podemos ver na figura 1 (BOTAU, 2004; ASSN, 2017): 
FIGURA 1: Conjunto etnolinguístico da Costa do Marfim

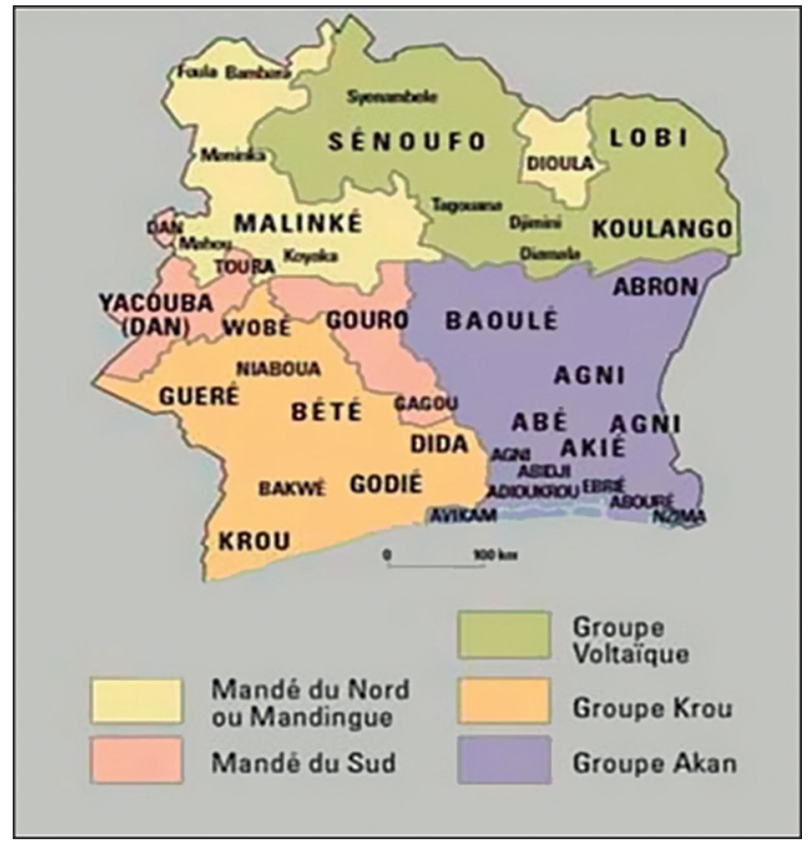

Fonte: ASSN (2017).

O grupo malinké, ao qual pertencia o escritor Ahmadou Kourouma, é composto por seis etnias, Koyaka, Mahouka, Bambara, Dioula, Camara e Mandinka, sendo este último o grupo demográfico mais expressivo (50\%), e o malinké é a língua falada pelos malinkés. Porém, os grupos étnicos não se limitam ao território da Costa do Marfim. O povo malinké, grande grupo da região Mandingue da África Ocidental, ocupou o norte da Costa do Marfim, o oeste de Burkina Faso, grande parte da Guiné, Guiné-Bissau, Gâmbia e Senegal. O nome malinké, significa o homem do Mandé ou Mali, do qual todos os grupos Mandingues se originam. Atualmente, os malinkés ocupam um território que inclui o sudoeste do Mali, sul do Senegal, leste da Guiné e noroeste da Costa do Marfim (ASSN, 2017).

Os malinkés eram conhecidos como um povo guerreiro, cujas conquistas se estendiam desde a Idade Média até o início do período colonial; e também foram grandes comerciantes. O período que cobre o surgimento e o apogeu do Império do Mali ou o Império Mandingue medieval se estendeu do século XIII ao XV. Em 1230, começa a formação do Estado Mandingue. Mali, que significa onde o rei vive, foi, no início do século 13, uma província subjugada ao domínio do reino Sosso, mas Soundjata Keita tira seu povo da dominação Sosso e, por isso, é considerado pelos povos do Mandingue o maior imperador do Mali. É graças ao poder militar e 
à excelência administrativa estabelecida por Soundjata que o império Mandingue conseguiu estender suas fronteiras. No século XV, esse império entra em declínio, com sua dissolução, sendo conquistado por outros povos. Foi apenas no século XIX que Almany Samory Touré fundou um reino muçulmano, com o espírito malinké de conquista e expansão. Samory Touré aumentou consideravelmente a área malinké e foi um dos maiores obstáculos para a conquista colonial da África Ocidental, visto que resistiu à penetração das tropas francesas até o início do século XX (ABIODUNENIAYEKAN, 2013). O avô de Ahmadou Kourouma foi, inclusive, um dos generais de Samory.

Ahmadou Kourouma passou sua infância em Togobala, na Guiné, que se tornará mais tarde a cidade natal de Fama, o personagem principal de Les Soleils des indépendances. Ele frequentou a escola primária em Bingerville, na Costa do Marfim, e a Escola Técnica Superior de Bamako, no Mali. Ao voltar para a Costa de Marfim, é recrutado para a armada colonial, mas, após recusar participar de um ato de repressão, é enviado à Indochina, no corpo de soldados senegaleses, onde vive de 1951 a 1954. Ali, atuou como jornalista, pois era um dos poucos soldados que sabia ler e escrever em francês. Após esta experiência, Kourouma vai estudar na França, onde faz Ciências Atuariais, uma formação útil ao seu país. Diplomado em Nantes, instala-se em Lyon e casa-se com uma francesa, entretanto, engajado com a situação política da Costa do Marfim, ele volta a seu país pouco antes da independência, em 1960 (CARMO, 2007).

A independência representou uma decepção para Kourouma e à luta anticolonialista segue-se o combate contra a nova orientação política encarnada no poder totalitário do presidente. Em 1963, Kourouma é preso, acusado de ter participado de um complô contra o presidente. Embora tenha sido uma situação criada para desmoralizar os rebeldes, ele foi libertado apenas depois que o presidente considerou o risco de mantê-lo na prisão, tendo em vista o fato de que sua mulher poderia alertar as autoridades francesas e criar problemas diplomáticos. Após ser liberado, passa sete meses em Abidjan, mas não encontra emprego porque as empresas foram proibidas de empregá-lo em razão de seu engajamento político e sua presumida implicação no complô. Durante esse período, começa a escrever seu primeiro romance Les Soleils des indépendances, concebido inicialmente como uma forma de denúncia contra os abusos da tirania e da corrupção. O romance foi rejeitado por vários editores franceses devido aos erros de língua francesa, visto que a obra não respeitava a língua formal francesa. Mas, após receber um prêmio literário do Québec, em 1968, e publicar o livro pela Presses de l'Université de Montréal, a editora francesa Éditions du Seuil compra, em 1970, os direitos de edição do livro (CARMO, 2007). 
Depois de Les Soleils des indépendances (1983), Kourouma escreveu, em 1990, Monnè, outrages et défis (Monnè, ultrajes e desafios), onde conta a descoberta da África pelos europeus, destacando a degradação causada pela colonização e os conflitos interculturais. Em 1998, publica En attendant le vote des bêtes sauvage (A espera do voto das bestas selvagens), em que apresenta a trajetória de Koyaga, um ditador que fica no poder graças à corrupção e a tirania. Nessa obra, o autor nos mostra que os povos africanos viveram regimes ditatoriais e foram submetidos à tirania depois da independência e durante a Guerra Fria. Em Allah n'est pas obligé (Alá não é obrigado), de 2000, encontramos um garoto de 10 anos, que conta seu caminho de órfão sem educação, que é obrigado a se tornar uma criança-soldado nas guerras tribais. Nela, o autor denuncia a violência das guerras na África do Oeste, especialmente em Serra Leoa, e o recrutamento de crianças para lutar nos exércitos rebeldes contra as forças governamentais. Além dessas obras, Kourouma dedicou-se igualmente à literatura para crianças, escrevendo sobre a cultura e os costumes da tradição africana (CARMO, 2007).

A literatura surge na vida de Kourouma como um modo de expor e denunciar os problemas na África causados pelos europeus. Essa necessidade concerne a toda uma geração de escritores africanos, seja em língua francesa, inglesa ou portuguesa, caso do escritor moçambicano Mia Couto. O poder ou a situação política tornamse temas constantes da literatura, um modo de expor os regimes políticos tirânicos que governam, desde a independência, por meio do terror e da violência. Os autores denunciam os sistemas de partidos únicos, e a aparência de democracia, bem como a elite nacional incompetente e corrupta e apresentam a vida dos heróis em busca de um novo mundo para o povo, acostumado com a miséria.

A criação romanesca da geração de escritores independentes torna-se uma forma de denúncia e de crítica aos regimes políticos ditatoriais, aos partidos únicos e à corrupção, bem como a contestação do modelo literário europeu. A literatura também se torna um veículo de informação etnográfica e sociológica, em uma busca por uma identidade nacional. Podemos dizer que o intelectual africano, envolvido com os problemas de seu país, vai desafiar a imagem da África que lhes é imposta de forma e empreender, por si mesmo, pesquisas sobre a África e os africanos, é isso que faz Ahmadou Kourouma.

Os romances de Kourouma são uma retomada ficcional da História, um testemunho (DIANDUE, 2003), como diz o escritor: "Escrevo coisas que são verdadeiras. Não escrevo para apoiar uma teoria, uma ideologia política, uma revolução, etc. Eu escrevo verdades, como eu as sinto, sem tomar partido. Eu escrevo as coisas como elas são." (KOUROUMA apud CARMO, 2007, p.31). Entretanto, é importante considerar, conforme as palavras do autor, que se trata de uma história, uma ficção: "Não é a História que eu conto, tomo as bases históricas 
a partir das quais eu analiso os fatos que eu conto [...] É minha ficção, é minha leitura da História [...] Quando um romancista trabalha, ele se baseia sempre em um personagem. Ele começa sempre com um personagem real e depois ele o transforma." (KOUROUMA apud CARMO, 2007, p.31). É o que ocorre no romance Les Soleils des indépendances.

\section{Les Soleils des indépendances}

Les Soleils des indépendances foi escrito quando os países africanos de língua francesa começam a dar seus primeiros passos como nações independentes e surge em meio às mudanças resultantes da colonização e da desilusão da independência. O romance é dividido em três partes, as quais são autônomas entre si, embora sua justaposição dê unidade ao texto. A narrativa conta a história de Fama Doumbouya, príncipe Horodougou, que vive no país Costa dos Ébanos (país que faz referência à Costa do Marfim), enquanto sua terra natal, Horodougou, território onde está a tribo Doumbouya e cuja capital é Togobala, encontra-se na República Socialista de Nikinai, país que faz fronteira com a Costa dos Ébanos (corresponderia à Guiné no romance). A referência geográfica é evidente na obra do escritor, no entanto há a substituição dos nomes reais de lugares, embora seja possível reconhecer os países aos quais o autor faz referência. Ele também muda os nomes de governantes locais, devido às implicações jurídicas (DIANDUE, 2003).

A narrativa começa com o funeral de Koné Ibrahima, realizado na capital da Costa dos Ébanos:

Houve uma semana que Koné Ibrahima, de raça malinké, acabara na capital, ou como se diz em malinké: ele não suportara um pequeno resfriado. Como todo malinké, quando a vida escapou de seus restos, sua sombra levantou-se, escarrou, vestiu-se e partiu para o longínquo país natal malinké a fim de aí fazer estourar a notícia funesta das obséquias. Por caminhos perdidos na selva desabitada, dois vendedores malinkés encontraram a sombra e reconheceram-na. A sombra andava depressa e não os cumprimentou. Os vendedores não se enganaram: "Ibrahima acabou", disseram eles. Na cidade natal a sombra mexeu e arrumou seus bens. Por trás da choupana ouviu-se bater as cantinas do defunto e suas cabaças serem esfregadas; mesmo seus animais se agitavam e baliam bizarramente. Ninguém se enganava: "Ibrahima Koné acabou, é sua sombra", disseram todos. A sombra voltara à capital para seguir as exéquias: ida e volta, mais de dois mil quilômetros. O tempo de piscar um olho! (KOUROUMA, 1970, p.7). 
O desejo do autor de afirmar suas origens faz-se evidente, considerando que a palavra malinké é repetida cinco vezes. O termo qualifica o indivíduo que pertence ao grupo malinké, mas também designa a língua e, para o leitor, essa ocorrência inicial funciona como um sinal, que será reiterado ao longo do romance e servirá para construir um universo dito malinké, que passa pela referência a personagens, com seus patrônimos e profissões, ao território e à língua. Aos poucos, o ser malinké surge como chave de compreensão da situação narrada e o leitor, considerado como não malinké, será guiado pelo universo malinké pelo narrador, ao longo do romance (VAN DEN AVENNE, 2005).

Temos no romance um narrador heterodiegético, aquele que não pertence à história que narra: ele fala dos personagens, o que são e o que fazem, e de suas relações. Sendo onisciente, ele sabe tudo e entra na consciência dos personagens, especialmente de Fama. Mas a oralidade, que faz parte das culturas autóctones, também se faz presente em Les Soleils des indépendances. O narrador apresenta por vezes a perspectiva de um contador tradicional, dirigindo-se a um público e dialogando com o leitor, surgindo então como um narrador-contador. Esse é o modo escolhido pelo autor para reproduzir a comunicação oral na narrativa. Vemos, assim, a junção de dois sistemas culturais, do oral e do escrito, assim como a presença de dois sistemas linguísticos, visto que a língua escrita, o francês, considerada uma língua de passagem, é interceptada constantemente pelo malinké (GAUVIN, 2007).

A introdução de estruturas lógicas cognitivas da língua malinké na língua francesa mobilizou parte da crítica acerca do romance. Kourouma reconhece que a língua foi um problema, visto que sentia sua impotência em colocar seus personagens na língua francesa. $\mathrm{O}$ autor buscou, então, meios para transferir a língua materna, o malinké, com sua carga emocional, seu pensamento, suas expressões e imagens na língua escrita. Tem-se então a inserção de um estilo e léxico completamente extrínseco à língua francesa, situação chamada de fiel traição, por Makhily Grassama (apud CARMO, 2007):

Ahmadou Kourouma tortura e trai a língua francesa como quem pretende manterse fiel à linguagem malinké com a qual parece ter "jurado uma santa aliança". [...] emprega as palavras da França para nelas inserir o pensamento de sua floresta natal; ele as destrói para destituí-las de qualquer valor e, progressivamente, as preenche com novos valores, que são os da sua região e que, às vezes, fazem as palavras brilharem como pepitas de ouro. (GRASSAMA apud CARMO, 2007, p.33)

A busca por transcrever as conotações africanas na língua francesa foi, de acordo com Grassama (1995, p.115, tradução nossa), a grande inovação de Kourouma, que, para isso, “[...] não apelou, como se poderia esperar, nem para 
a gíria, nem para a língua popular, nem para o pidgin da Costa do Marfim ou o petit-nègre." Essa particularidade do romance pode ser percebida ainda no primeiro parágrafo, quando o narrador diz: "Koné Ibrahima, de raça malinké, acabara na capital, ou como se diz em malinké: ele não suportara um pequeno resfriado" (KOUROUMA, 1970, p.7). Aqui, o verbo acabar aparece como verbo intransitivo, sendo um eufemismo malinké para morrer, o qual será confirmado com o processo de tradução a partir de "como se diz em malinké", quando o narrador assinala a passagem para o imaginário malinké, apresentando uma expressão própria da língua que significa morrer. Ao inserir uma tradução malinké, Kourouma faz com que a locução seja vista como standard, ou seja, como parte da língua de comunicação. O mesmo recurso é usado no trecho a seguir, onde o narrador explica o título do romance ao leitor não malinké: “[...] se não estivéssemos na era das Independências (os sóis das Independências, dizem os malinkés), eu juro [...]" (KOURUMA, 1970, p.9, grifo nosso). A partir da explicação, entendemos que os sóis das independências correspondem ao modo como os malinkés veem os novos tempos, a nova era. Além disso, o plural, "os sóis", diz respeito igualmente ao conjunto do processo de independência dos países sob o domínio da colonização francesa.

O termo "sombra" presente no trecho do romance citado anteriormente também causa estranhamento, visto que faz referência não a um ser vivo, mas a um indivíduo após sua morte. A sombra levanta-se, escarra, veste-se, caminha, move objetos e volta para perto do corpo morto para seu funeral. Essa fusão da realidade com o sobrenatural cria um ambiente extraordinário e revela uma maneira particular de ver a relação entre a vida e a morte, já que a vida parece continuar, mesmo depois da morte do corpo (COUSSY, 2000). Para os malinkés, após a morte, a sombra, ou o espírito do morto, caminha até sua terra natal para avisar de sua partida. Em seguida, ele volta para conduzir o cortejo fúnebre, sentado sobre o caixão. O funeral se desenrola durante quarenta dias de festa e é acompanhado pela sombra, invisível para o malinké comum. Participam desta festa, amigos, parentes e mesmo transeuntes que depositam oferendas e sacrifícios. Depois disso, a sombra parte definitivamente e voltará reencarnada em um bebê malinké. Ao descrever a cerimônia fúnebre, o narrador faz referência à figura do griot:

Como toda cerimônia funerária rende, compreende-se que os griots malinkés, os velhos malinkés, aqueles que não vendem mais porque arruinados pelas Independência (e só Alá pode contar o número de velhos comerciantes na capital arruinados pelas Independências!) "trabalham" todos nas exéquias e nos funerais. Verdadeiros profissionais! Noite e dia eles andam de bairro em bairro para assistir a todas as cerimônias. Entre os malinkés, eles são chamados muito maldosamente, “os abutres" ou "bando de hienas". (KOUROUMA, 1970, p.8). 
O griot era inicialmente um músico na África ocidental, mas pode ser compreendido também como guardião da tradição e da literatura oral africana. Sua atividade essencial é contar os mitos e as histórias do passado e narrar ou cantar os nomes e as ações heroicas dos ancestrais. Para os povos do Mandigue, a tradição oral está presente nos discursos e cantos produzidos pelos griots em cerimônias que marcam eventos importantes na vida social, como o nascimento, o casamento ou a morte. No ritual, suas palavras são acompanhadas e validadas por danças, músicas e doações (ZEMP, 1966). Entretanto, no romance de Kourouma, a imagem do griot é descrita de maneira negativa, porque suas funções tradicionais foram corrompidas pelos novos tempos. O griot torna-se um verdadeiro profissional e o aspecto econômico de sua atividade parece mais importante do que o caráter simbólico. Os griots “[...] trocaram o ouro por cobre. Eles são apenas animadores públicos que exibem os ornamentos de sua eloquência por algumas moedas [...] Se os griots rompem com sua função primária [...] isso é um sinal, desfavorável, do futuro da cultura maliana." (DOUYON apud OGIER-GUINDO, 2010, tradução nossa).

Em Kourouma, a tragédia da colonização e a era das independências atingem os malinkés de tal forma que mesmo o príncipe Horodougou, que deveria estar no meio da riqueza via-se em uma situação miserável: "Ele, Fama, nascido no ouro, no comer, na honra e nas mulheres! Educado para preferir o ouro ao ouro, para escolher o comer entre outros e deitar com sua favorita entre cem esposas! O que se tinha tornado ele? Uma carcaça ambulante..." (KOUROUMA, 1970, p.10). Despojado de seu título, de seus bens e, sob os "sóis das independências", Fama é obrigado a sair de funeral em funeral, coletando doações das cerimônias, seu único meio de sobrevivência, sendo, por isso, insultado e humilhado:

- Os descendentes de grandes guerreiros (era Fama!) viviam de mentiras e de mendicância (ainda era Fama); autênticos descendentes de grandes chefes (sempre Fama) haviam trocado a dignidade pelas plumas dos abutres e procuravam o cheiro penetrante de um acontecimento - nascimento, casamento, enterro - para pular de cerimônia em cerimônia. (KOUROUMA, 1970, p.15).

Como os griots, Fama, o príncipe Doumbouya, outrora honrado torna-se um príncipe deposto, que vai de uma cerimônia a outra, vivendo dos restos ofertados povo malinké. Reduzido à imagem de "abutre", de "hiena", animais que vivem dos restos deixados pelos outros, Fama torna-se um animal. Despojado de todos os seus bens, Fama também se vê despojado de sua humanidade e através dessa metáfora, o novo status do personagem se desenha: 
Fama Doumbouya! Verdadeiro Doumbouya [...], último e legítimo descendente dos príncipes Doumbouya de Horodougou, totem pantera, era um "abutre". Um príncipe Doumbouya! Totem pantera juntava-se com as hienas. Oh! Os sóis das Independências! (KOUROUMA, 1970, p.9).

Fama passa pelos períodos da colonização e da independência e para pensar sua situação, é preciso compreender o impacto das modificações produzidas pela administração colonial na sociedade existente durante esse período. Quando chegaram na região oeste da África, os europeus perceberam que o poder da organização político-religiosa se concentrava na figura dos chefes autóctones. Em decorrência disso, viram a necessidade de estabelecer acordos que assegurassem a soberania europeia nas regiões ocupadas, a livre circulação e o comércio dos produtos e os meios encontrados pelos franceses para seduzir e comprometer os africanos nos acordos e tratados era o pagamento regular com produtos como fuzis, pólvora, tabaco e álcool. Quando ocorre uma ruptura das relações diplomáticas, a França coloca em prática políticas que visam enfraquecer a autoridade dos chefes tradicionais e substitui-los pela administração colonial. Diante de estruturas preexistentes já organizadas, com sociedades com uma estrutura monárquica baseada no exercício do poder hereditário, os franceses decidem manter as cheferias tradicionais, mas substituir os velhos chefes analfabetos por intelectuais e universitários, provocando uma modernização e a intelectualização dos poderes tradicionais. Para que a gestão fosse eficaz e a ordem mantida, a administração ocorria à distância, de modo que o intelectual nomeado permanecia na cidade, enquanto seu adjunto, através de uma procuração, administrava pessoalmente a aldeia (CARMO, 2007). Para Fama, esse período é doloroso, porque marca a tomada do poder das monarquias locais e sua decadência, visto que é nessa época que ele se vê destituído de sua posição e substituído por seu primo Lacina:

Seu pai morto, o legítimo Fama deveria sucedê-lo como chefe de todo o Horodougou. [...] Primeiro porque um rapazinho, um pequeno enfeite europeu de administrador, sempre de calças curtas e sujas, agitado e grosseiro como a barbicha de um bode, comandava o Hororodugu. Evidentemente Fama não podia respeitá-lo; suas orelhas ficaram vermelhas e o comandante preferiu, sabem quem? O primo Lacina, um primo distante [...] (KOUROUMA, 1970, p.19).

Fama perdeu o direito à chefia de Togobala devido a seu desprezo pelo administador colonial e por não reconhecer a autoridade europeia no Horodougou. Diante de sua recusa em submeter-se às regras impostas, um novo chefe é anunciado entre os Doumbouya: Lacina, um jovem sem experiência, que sabe ler e escrever na 
língua do colonizador e concorda com as diretrizes estabelecidas pela administração colonial. Assim, os costumes ancestrais seculares fundados na herança sanguínea dos chefes saídos da dinastia são perdidos nos novos tempos.

A partir de então, Fama torna-se inimigo do sistema colonial, combatendo-o incessantemente e, por esse motivo, ele apoia a chegada de uma nova era que será aquela das independências. Para a monarquia nativa arruinada pelo colonialismo, a transição para a independência seria a ocasião de recuperar a supremacia política e econômica, por isso ela lutou contra a colonização e a favor da independência, mas a nova estrutura político-administrativa não implicava mais o retorno a uma gestão tradicional, inadaptada ao Estado moderno. A antiga classe dirigente marginalizada pela independência vê-se rejeitada porque era baseada em valores ancestrais de honra e dignidade, incompatíveis com a nova ideologia, baseada na individualidade e no dinheiro. Desse modo, a sociedade das independências não responde às expectativas da antiga classe, a qual vê-se relegada definitivamente à marginalização com a chegada do Estado moderno. A situação dessa aristocracia representa as dificuldades encontradas pelas sociedades africanas durante o período de transformação política, econômica e cultural. Os tempos transformam-se e o sistema social tradicional não tem lugar na sociedade moderna, situação que tem como resultado um profundo ressentimento.

Com a morte do primo Lacina, Fama torna-se o herdeiro de Togobala, segundo as leis ancestrais que fixam as normas de sucessão no reino do Horodougou, mas essa decisão deve ser aprovada pela administração do partido único. Assim, motivado pelo dever de assistir aos funerais e o desejo de reabilitar o posto de chefe da tribo, depois da morte do primo, Fama decide viajar a Togobala, seu vilarejo natal e capital do Horodougou, que está localizado na República Popular do Nikinai.

Togobala seria a cidade mítica, lugar onde há uma comunicação entre os homens e os deuses. É nesse lugar que se fundou a dinastia do povo Doumbouya, sendo Fama o último descendente legítimo de Souleymane, fundador da dinastia e ancestral mítico que tem as características de um grande rei e líder. Em sua juventude, Fama teve uma vida despreocupada, pois conheceu a riqueza material e os privilégios de sua posição. Por isso, no inconsciente individual do personagem, Togobala é um espaço paradisíaco. A ausência de sofrimento e a abundância de alimento não o preparam para as dificuldades que ele enfrenta com a chegada da colonização na África. A grandeza do passado é rompida dando passagem aos novos tempos onde reinam a fome, as epidemias e a seca (GUÉDALLA, 2015). É isso que ele encontra quando chega a Togobala:

Como herança, nada de polpudo, nada de pesado, nada de gordo. Até uma galinha espantada poderia fazer-lhe a volta. Oito casas em pé, apenas em pé, com paredes 
rachadas do teto ao chão, o teto de palha negro e velho de cinco anos. Muito a fazer e a cobrir antes da grande invernada. O estábulo vazio à frente; grande casa comum, onde eram amarrados os cavalos, não se lembrava mais nem do cheiro da urina. Entre os dois, a pequena casa dos caprinos que continha ao todo: três bodes, duas cabras e um cabritinho, famélicos e fedorentos, destinados a ser degolados nos feitiços de Balla. Na verdade, de humanos, poucos braços trabalhadores. Quatro homens, dos quais dois velhos, nove mulheres das quais sete velhotas que se recusam a morrer. Dois cultivadores! Jamais dois lavradores tinham rins bastante para encher quatorze comedores, inverno e verão! E os impostos, as cotizações do partido único e todas as outras contribuições monetárias e bastardas da independência, de onde tirá-los? Fama, na verdade, não estava certo do real, do sólido, do definitivo... (KOUROUMA, 1970, p.93).

Fama herdará um reino arruinado e sem riquezas:

Em nome da grandeza dos ancestrais, Fama esfregou os olhos para se certificar que ele não se enganava. De Togobala da sua infância, Togobala que ele tinha no coração, não restava nem o último cheiro do último peido. Em vinte anos o mundo não tinha, no entanto, acabado. E eis aí o que existia. De longe em longe uma ou duas casas inclinadas, um tanto velhas, torradas pelo sol, isoladas como cupinzeiros em uma planície. Entre as ruínas do que tinham sido concessões, lixos e ervas que os animais tinham pastado, pelo fogo queimadas e pelo verão lambidas. Crianças fugidas das casas [...] titubeando sobre pernas de hastes de milho e balançando pequenas cabaças de ventres empoeirados. (KOUROUMA, 1970, p.88).

Togobala deveria representar a grandeza do passado diante das transformações da modernidade, no entanto, em meio ao espaço paradisíaco de sua infância, Fama vê a degradação. No Horodougou, a ruína material do lugar é partilhado pelos habitantes, assim, a descrição dos lugares e das casas, pobres cabanas destruídas pelo sol ardente, reflete a condição dos habitantes do local. A pobreza gangrena tudo, como vemos na descrição do estado físico das crianças, de modo que a vida se torna difícil nesse lugar.

A degradação física revela a degradação moral, na medida em que Diamourou, o griot Doumbouya, responsável por defender a tradição, sobrevive à miséria de Togobala graças ao dinheiro de sua filha, concubina de um comandante branco. Balla, um velho feiticeiro, por sua vez, tornou-se o homem mais rico do lugar, porque os malinkés usam sempre seus feitiços e, independentemente dos resultados, os serviços sempre são pagos. Desse modo, vemos que o espaço do Horodougou se 
transforma com as novas práticas e ideias, os valores tradicionais são ignorados e deturpados e há o enriquecimento de grupos que deveriam representar da tradição.

Se Fama lutou contra a colonização e a favor de transformações que viriam com a independência, a nova era criou novas estruturas que fragilizam ainda mais as monarquias e acabam por destruir definitivamente as tradições e os valores que ele busca defender e preservar. Com a independência, tem-se efetivamente o fim da realeza e o início de uma nova era, que será, como diz Fama, o "reino da corrupção": a corrupção na natureza, a alteração da cultura e a desordem na sociedade, transformando drasticamente as relações do homem com sua terra natal. Para Fama: "[...] a colonização, os comandantes, as requisições, as epidemias, as secas, as independências, o partido único, a carta de identidade e a revolução são estranhos no Horodougou, são tipos de maldições inventadas pelo diabo [...]" (KOUROUMA, 1970, p.137), ou seja, pelo europeu. A ação do homem modificou o curso da história para dar nascimento a uma sociedade improdutiva, onde a terra natal é dessacralizada.

Com as independências, o Horodougou, território sagrado dos Doumbouya, é dividido em dois territórios que pertencem a países distintos, Nikinai e Costa dos Ébanos, os quais possuem ideologias antagônicas: o Socialismo e a República, respectivamente. As ideologias ocidentais assolam, assim, o imaginário africano e passam a regular a nova sociedade do Mandingue. Os partidos únicos, após a independência, substituem o poder colonial e tornam-se as novas autoridades, transtornando, desse modo, a hierarquia dos vilarejos do Horodougou e o exercício do poder do chefe. Com as políticas totalitárias, o povo foi privado do que ele tem de mais valioso: sua cultura, seus costumes e sua alma (GUÉDALLA, 2015).

$\mathrm{O}$ romance apresenta experiências de alguns personagens que vivem no Nikinai e que tiveram suas vidas transformadas com as mudanças políticas decorrentes da independência. Com a criação do partido único, ou seja, a ditadura socialista, era preciso aderir ao partido único L.D.N, e, por conseguinte, pagar uma cotização para cada indivíduo da família, suas propriedades (animais, carros, etc.); também era preciso pagar as cotizações desde a criação do partido único, quer dizer, pagar dez anos de cotizações em relação a todos os bens. A partir dessa situação, muitos indivíduos perderam suas propriedades, a liberdade de expressão e o direito de ir e vir. Ainda havia aqueles que perderam a vida por se rebelar contra o novo sistema. Os novos tempos também fazem com que Fama se confronte pela primeira vez com a exigência da carta de identidade, ao atravessar a fronteira que separa os países. Esse objeto the é completamente estranho e, como não tem uma, o príncipe Doumbouya só consegue atravessar, porque um guarda o reconhece e, respeitando ainda as tradições, o deixa passar sem documentos. 
Fama depara-se com o absurdo da situação: os dois países ocupam terras Horodougou que pertenceram, outrora, aos Doumbouya, ou seja, à sua família; no entanto, na nova era, ele é visto como um estrangeiro nas terras de seus antepassados e precisa de um documento dizendo quem ele é para passar de um país a outro. No final do romance, o personagem morre no Horodougou e a morte do último descendente dos Doumbouya marca o fim dessa dinastia secular e com ela a força da tradição e dos ideais do passado.

\section{Conclusão}

Por causa da instituição do Estado-nação, Fama perde a ligação com a única comunidade que conheceu como legítima até então e ele não pode encontrar um sentido no novo sistema social. Ele representa não apenas a trajetória de um nobre malinké sem seus direitos e privilégios, mas simboliza o destino de muitos homens que não entendem ou aceitam as consequências da colonização.

A ruina de Togobala, e, portanto, do Horodougou, simboliza a morte da tradição, embora esta resista ainda na figura de Fama que, mesmo diante da nova realidade, continua a viver no imaginário antigo, no qual o Horodougou ainda é um vasto império. Preso aos valores ancestrais, o príncipe Doumbouya não compreende e não se adequa às novas exigências da era das independências, sendo confrontado com o absurdo do mundo em que vive. Como nos lembra Zouagui (2013), ele é como Dom Quixote, em ruptura total com a realidade que o envolve e encarna a condição trágica e absurda do homem africano da era pós-colonização, cujo destino Kourouma buscou apresentar-nos em Les Soleils des indépendances.

\section{The age of independence in Ahmadou Kourouma's WORK}

ABSTRACT: The Ivorian writer Ahmadou Kourouma (1927-2003) addresses the theme of African colonization and the dawn of independence in The Suns of Independence, a novel published in 1968. Starting from the social context of the Ivory Coast of the 1960s, the author creates a fictional work that allows us a glimpse of its postcolonial universe through the evolution of the character Fama, a Horodougou prince stripped of his title, his property and his dignity. We intend to observe in this article how the process of colonization and independence in the Ivory Coast took place and to consider the question of the degradation of Malinké tradition in the era of independence, from the perspective presented by Ahmadou Kourouma in the novel.

KEYWORDS: Ahmadou Kourouma. Les Soleils des indépendances. Colonisation. Independence. 


\section{REFERÊNCIAS}

ABIODUN-ENIAYEKAN, E. N. L'écrivain comme historien: une étude de quelques romans d'Ahmadou Kourouma. 2013. 260f. Thèse (Doctorat en études françaises) - College of development studies, Covenant University, Ota, Nigeria, 2013.

AFRICAN SECURITY SECTOR NETWORK [ASSN]. Les Malinké en Côte d'Ivoire, Analyse sociétale africaine, Madina, fév. 2017. Disponível em: $<$ http://africansecurity network.org/assn/wp-content/uploads/2017/02/Les-Malinke\%CC\%81-en-Cote-dIvoire.pdf $>$. Acesso em: 22 nov. 2017.

BOAHEN, A. A. (Dir.). Histoire générale de l'Afrique: l'Afrique sous domination coloniale, 1880-1935. Paris: Éditions UNESCO, 1987. v.7.

BOTAU, A. B. (Org.). Intégration et autonomie des minorités en Côte d'Ivoire. Document de travail du Groupe de travail sur les minorités, COMMISSION DES DROITS DE L'HOMME Sous-Commission de la promotion et de la protection des droits de l'homme. Abidjan: Université de Cocody, 2004. Disponível em: <http://www2.ohchr.org/english/ issues/minorities/docs/2004-WP8fr.doc>. Acesso em: 22 nov. 2017.

CARMO, M. S. M. do. Les soleils des Indépendances: da sociedade sólida ao prelúdio dos laços efêmeros. 2007. 216f. Tese (Doutorado em Língua e Literatura Francesa) Universidade de São Paulo, Faculdade de Filosofia, Letras e Ciências Humanas, São Paulo, 2007.

COUSSY, D. La littérature africaine moderne au sud du Sahara. Paris: Karthala, 2000.

DAGO, G. J. Histoire économique et sociale de la Côte d'Ivoire de 1843 à nos jours. Paris: L'Harmattan, 2016.

DIANDUE, B. K. P. Histoire et fiction dans la production romanesque d'Ahmadou Kourouma. 2003. 644 f. Thèse (Doctorat en Littérature comparée) - École Doctorale des Sciences de l'Homme et de la Société, Université de Limoges, Limoges, 2003.

FRANCE. Assemblée nationale. Chambre des députés. Annales de la Chambre des députés. Session ordinaire. 1894, t.II. Disponível em: $<$ https://archive.org/details/annales delacham01unkngoog>. Acesso em: 22 nov. 2017.

GAUVIN, L. L'écrivain francophone et ses publics. Paris: Les Éditions Karthala, 2007.

GOBINEAU, A. Essai sur l'inégalité des races humaines. Chicoutimi: J.-M. Tremblay, 2004.

GRASSAMA, M. La langue d'Ahmadou Kourouma, ou Le français sous le soleil d'Afrique. Paris: ACCT, 1995. 
GUÉDALLA, O. L'Itinéraire spatial de Fama dans Les Soleils des Indépendances d'Ahmadou Kourouma. Les Cahiers du GRELCEF, London, n.7, p.51-64, 2015.

KOUROUMA, A. Les soleils des indépendances. Paris: Editions du Seuil, 1983. (Points Roman, 419).

O sol das independências. Tradução de Marisa Murray. Rio de Janeiro: Nova Fronteira, 1970.

MANCERON, G. Les paradoxes de l'orientalisme. In: FABRE, T. Colonialisme et postcolonialisme en Méditerranée. Marseille: Édition Parenthèses, 2004. p.59-69.

OGIER-GUINDO, J. Le griot manding, artisan de la construction sociale: étude d'un chant jula. Signes, Discours et Sociétés [en ligne], Villejuif, v.6, déc. 2010. Não paginado. Disponível em: <http://www.revue-signes.info/document.php?id=2074. ISSN 1308-8378>. Acesso em: 22 nov. 2017.

PENNA FILHO, P.; BADOU, K. R. A França na África: as intervenções militares e suas motivações - o caso da Costa do Marfim. Carta Internacional, v.9, n. 2, p. 156-172, jul.dez. 2014.

RENAN, E. La réforme intellectuelle et morale de la France. Cambridge: At the University Press, 1950.

THIMONIER, O. (Coord.). La France coloniale d'hier et d'aujourd'hui. Paris: Bambel, 2006.

VAN DEN AVENNE, C. Passer d'un monde à l'autre, d'une langue à l'autre: Lecture de deux incipt d'Ahmadou Kourouma. MOCHET, M. A. et al. (Org.). Plurilinguisme et apprentissages: Mélanges Daniel Coste. Lyon: ENS, 2005. p.237-246.

ZEMP, H. La légende des griots malinké. Cahiers d'Études africaines, Paris, v.24, p.611-642, 1966.

ZOUAGUI, S. La mort de Fama dans Les soleils des indépendances d'A. Kourouma: entre logique mythique et logique romanesque. Multilinguales, Bejaia, v.1, n.1, p.45-55, 2013.

Recebido em 08/02/2018.

Aprovado em 18/04/2018. 
